\title{
Changes in retinal nerve fiber layer thickness following mechanical microkeratome-assisted versus femtosecond laser-assisted LASIK
}

This article was published in the following Dove Press journal:

Clinical Ophthalmology

24 September 2013

Number of times this article has been viewed

\author{
Mohamed Hosny' \\ Rania M Zaki' \\ Rania A Ahmed' \\ Noha Khalil' \\ Hoda M Mostafa' \\ 'Department of Ophthalmology, Cairo \\ University, Cairo, Egypt
}

Purpose: To study the influence of the transient elevation of intraocular pressure during suction in laser-assisted in situ keratomileusis (LASIK) on the retinal nerve fiber layer (RNFL) thickness both in microkeratome assisted and femotsecond (FS) LASIK.

Patients and methods: An interventional case series that included 40 eyes suffering from myopia who were candidates for LASIK. All underwent Wave Front Guided LASIK by the same surgeon using the VisX CustomVue platform. A corneal flap was created in 20 eyes using a mechanical microkeratome Moria M2 (MMK), while the IFS IntraLase ${ }^{\text {TM }}$ was used in the remaining 20 eyes. Mean suction time was recorded from "Suction ON" to "Suction OFF" time. Optic cube and RNFL thickness analysis using Spectral Domain Optical Coherence Tomography (SD-OCT) Cirrus-HD was completed before, and 1 month after LASIK. Results: The study included 40 eyes of 20 patients. All were females with mean age $33.5 \pm 6.4$ years. Mean preoperative spherical equivalent was $-3.62 \pm 2.31 \mathrm{D}$. Average preoperative RNFL thickness was $94.6 \pm 12.1 \mu \mathrm{m}$ in MMK group while the postoperative average thickness was 95.1 \pm 11.9 um with no statistically significant difference ( $P$-value: 0.37$)$. Average preoperative RNFL thickness was $108.28 \pm 8.4 \mu \mathrm{m}$ in FS group compared to $108.38 \pm 11.2 \mu \mathrm{m}$ in the postoperative average with no statistically significant difference ( $P$-value: 0.94$)$. Mean "Suction ON" to "Suction OFF" time was 22 seconds in the MMK group compared to 41 seconds in the FS group.

Conclusion: The rise of intraocular pressure during application of suction ring in LASIK surgery does not affect the RNFL thickness as measured by SD-OCT, whether the flap is created by MMK or FS.

Keywords: intraocular pressure, laser-assisted in situ keratomileusis, retinal thickness

\section{Introduction}

Over the past 15 years, laser-assisted in situ keratomileusis (LASIK) has become the most popular refractive procedure. It has dominated the refractive surgery arena with its relative safety. This procedure involves a transient elevation in intraocular pressure (IOP) by the suction ring, and as most of the operated patients are myopic, concerns about retinal nerve fiber layer (RNFL) damage and optic nerve affection are justified. ${ }^{1}$

Femtosecond (FS) machines have revolutionized the creation of flaps for LASIK using a neodymium laser at $1,053 \mathrm{~nm}$ to dissect corneal tissue through microphotodisruption. This has increased the ability to create very uniform and thin flaps with greater biomechanical stability. These machines have been shown to elevate the IOP to a lower extent than traditional mechanical microkeratomes (MMKs); however, the "suction ON" to "suction OFF" time is considerably higher. ${ }^{2}$ Vetter et $\mathrm{al}^{3}$ showed IOP elevation up to $150 \mathrm{mmHg}$ with flat corneal applanation interfaces and up to $65 \mathrm{mmHg}$ with curved corneal interfaces.
Correspondence: Mohamed Hosny 84 Shehab Street, Mohandeseen,

Giza, Egypt, |24I I

Tel +201000007675

Fax +200233372117

Email mohamedhosny@me.com 
Optical coherence tomography (OCT) is a noninvasive quantitative objective method that provides a real-time in vivo image of the retina. ${ }^{4}$ Spectral Domain (SD)-OCT uses a diode laser wavelength of $840 \mathrm{~nm}$ with a scan rate of at least 20,000 axial measurements per second, thus providing better resolution compared to earlier time domain OCT. Therefore, better image acquisition with fewer artifacts becomes feasible with the possibility of generating three-dimensional images. ${ }^{5,6}$

Many studies reported the use of SD-OCT in evaluating RNFL thickness and its value in detecting glaucomatous damage with moderate to reasonably high sensitivity. ${ }^{1,45}$ It is noted that RNFL thickness measurements obtained by different SD-OCT machines are not entirely compatible and should not be used interchangeably. ${ }^{7}$

The aim of this study is to assess the influence of the transient elevation of IOP during suction in LASIK on the RNFL thickness both in microkeratome-assisted and FS laser-assisted LASIK.

\section{Material and methods}

This is an interventional case series that included 40 myopic eyes of 20 patients scheduled for LASIK treatment. Patients were subdivided into two groups, each including ten patients. Following the rules of our ethical committee, each patient was treated with the same modality in both eyes.

All patients had a complete ophthalmological examination, corneal pachymetry, and topography to rule out any LASIK contraindications (for example, ocular disease, ocular surface disorder, glaucoma, corneal thickness below 500 microns, and/or irregular corneal topography). Patients who had previous ocular or refractive surgeries were excluded, as well as patients who had peripapillary atrophy upon fundus examination.

Under topical anesthesia, all patients underwent wavefront-guided LASIK treatment using the VISX ${ }^{\mathrm{TM}}$ CustomVue platform (VISX ${ }^{\mathrm{TM}}$, (Abbott Medical Optics Inc., Santa Clara, CA, USA) by the same surgeon. The eye was fixated by a suction ring using $60 \mathrm{mmHg}$ negative pressure that was gradually built. A corneal flap, 110 microns thick, was created using a 90-micron head MMK (Moria M2; Moria, Antony, France) in 20 eyes, while the remaining 20 eyes had a 100 -microns thick corneal flap created by IFS IntraLase ${ }^{\text {TM }} 150 \mathrm{HZ}$ (Abbott Medical Optics Inc., Santa Ana, CA, USA).

The time of suction applied to the eye from "Suction ON" to "Suction OFF" was documented in each group, as were any intraoperative complications.

Goldmann applanation tonometry for IOP, as well as RNFL thickness measurements before, 1 week after, and
1 month after LASIK, were obtained. An SD-OCT instrument (Cirrhus-HD OCT; Carl Zeiss Meditec AG, Jena, Germany) was used. The optical resolution of this machine is $\sim 5 \mu \mathrm{m}$ axially and $\sim 25 \mu \mathrm{m}$ transversely with a scan speed of 27,000 axial scans per second.

All measurements were taken between 11 am and $1 \mathrm{pm}$ to eliminate the effect of diurnal variations on IOP, and any possible effect on RNFL thickness.

\section{Statistical analysis}

RNFL thickness parameters (overall average, superior average, inferior average, as well as nasal and temporal averages) were recorded and analyzed for mean and standard deviation values for both preoperative and postoperative measurements. Recorded parameters in the postoperative visits were compared to the preoperative parameters using Student's paired $t$-test. Intergroup differences were evaluated using the independent samples $t$-test. A $P$-value below 0.05 was considered statistically significant.

\section{Results}

This study included 20 female patients (40 eyes) with a mean age of $33.5 \pm 6.4$ years. The mean preoperative spherical equivalent was $-3.62 \pm 2.31$ diopters. The average preoperative RNFL thickness was $94.6 \pm 12.1 \mu \mathrm{m}$ in the MMK group and $108.28 \pm 8.4 \mu \mathrm{m}$ in the FS group. No statistically significant difference was found between both groups with regards to these parameters.

The mean "Suction ON" to "Suction OFF" time was $22 \pm 1.2$ seconds in the MMK group compared to $41 \pm 0.8$ seconds in the FS group. The LASIK procedure was uneventful in all patients.

The mean RNFL thickness values, as well as the values in each quadrant in both pre-LASIK and 1 month post-LASIK scans are shown in Tables 1 and 2 for the MMK-assisted

Table I Mean RNFL thickness value in $\mu \mathrm{m}$ measured by OCT before and after microkeratome-assisted LASIK

\begin{tabular}{|c|c|c|c|}
\hline Parameters & $\begin{array}{l}\text { Preoperative } \\
\text { (Mean } \pm \text { SD) }\end{array}$ & $\begin{array}{l}\text { I month } \\
\text { postoperative } \\
(\text { Mean } \pm \text { SD) }\end{array}$ & $P$-value \\
\hline $\begin{array}{l}\text { Average RNFL } \\
\text { thickness }\end{array}$ & $94.6 \pm 12.1 \mu \mathrm{m}$ & $95.1 \pm 11.9 \mu \mathrm{m}$ & 0.37 \\
\hline Superior average & $122 \pm 20 \mu \mathrm{m}$ & $120.7 \pm 19.7 \mu \mathrm{m}$ & 0.37 \\
\hline Inferior average & $120.1 \pm 11.2 \mu \mathrm{m}$ & $122.2 \pm 1 \mathrm{I} .46 \mu \mathrm{m}$ & 0.11 \\
\hline Temporal average & $65.1 \pm 13.4 \mu \mathrm{m}$ & $66.3 \pm 13.5 \mu \mathrm{m}$ & 0.27 \\
\hline Nasal average & $70.9 \pm 10.7 \mu \mathrm{m}$ & $70.9 \pm 12.2 \mu \mathrm{m}$ & 0.48 \\
\hline
\end{tabular}

Abbreviations: RNFL, retinal nerve fiber layer; OCT, optical coherence tomography; LASIK, laser-assisted in situ keratomileusis; SD, standard deviation. 
Table 2 Mean RNFL thickness value in $\mu \mathrm{m}$ measured by OCT before and after femtosecond-assisted LASIK

\begin{tabular}{lcll}
\hline Parameters & $\begin{array}{l}\text { Preoperative } \\
\text { (Mean } \pm \text { SD) }\end{array}$ & $\begin{array}{l}\text { I month } \\
\text { postoperative } \\
\text { (Mean } \pm \text { SD) }\end{array}$ & P-value \\
\hline $\begin{array}{lccc}\text { Average RNFL } \\
\text { thickness }\end{array}$ & $108.28 \pm 8.4 \mu \mathrm{m}$ & $108.38 \pm 11.2 \mu \mathrm{m}$ & 0.94 \\
Superior average & $1 \mathrm{II} .25 \pm 9.5 \mu \mathrm{m}$ & $1 \mathrm{I} 0.85 \pm 1 \mathrm{I} .4 \mu \mathrm{m}$ & 0.77 \\
Inferior average & $111.8 \pm 10.5 \mu \mathrm{m}$ & $1 \mathrm{II} .87 \pm 8.6 \mu \mathrm{m}$ & 0.95 \\
Temporal average & $85.5 \pm 15 \mu \mathrm{m}$ & $86.6 \pm 15.9 \mu \mathrm{m}$ & 0.59 \\
Nasal average & $79.2 \pm 6.9 \mu \mathrm{m}$ & $77.5 \pm 7.1 \mu \mathrm{m}$ & 0.28 \\
\hline
\end{tabular}

Abbreviations: RNFL, retinal nerve fiber layer; OCT, optical coherence tomography; LASIK, laser-assisted in situ keratomileusis; SD, standard deviation.

group and the FS-assisted group, respectively, with no statistically significant differences in either group, or between both groups $(P>0.05)$. It is worth mentioning that the same RNFL thickness values were reported at 1 week and 1 month post-LASIK. The IOP measurements at each visit were within normal ranges, with no antiglaucoma medications.

\section{Discussion}

In the current study, SD-OCT was used to evaluate the effect of applied suction during LASIK procedures on RNFL thickness in 40 myopic eyes, whether the flap was created by microkeratome or FS laser. LASIK-induced corneal alterations do not affect OCT imaging, making the latter (OCT imaging) reliable in RNFL thickness evaluation in treated eyes. The transient rise of IOP during suction was found to have no significant effect on RNFL thickness in either group.

Gürses-Özden et al ${ }^{8}$ as well as Tsai and $\operatorname{Lin}^{9}$ reported that RNFL thickness may decrease after uncomplicated LASIK procedures when measured by conventional scanning laser polarimetry (SLP) with a fixed corneal compensator. Yet in 2001, Gürses-Özden et al ${ }^{10}$ came to the conclusion that LASIK does not affect the RNFL thickness, as measured by OCT, SLP, and scanning laser tomography. The authors found that the changes present in the SLP thickness measurements were due to corneal alterations. ${ }^{10}$ Centonfanti et $\mathrm{al}^{11}$ as well as Zangwill et a ${ }^{12}$ confirmed these previous findings, and stated that the post-LASIK thinning of RNFL measured using SLP with a fixed corneal compensator can occur due to altered corneal birefringence, and may not actually be present.

Consequently, it is mandatory that changes in corneal birefringence are compensated for individually to obtain accurate RNFL thickness measurements. ${ }^{12}$ This fact was further supported by Dada et al, ${ }^{13}$ who used a glaucoma diagnostic variable corneal compensator (GDx VCC; Carl Zeiss Meditec
AG) in SLP and found no difference in RNFL thickness pre- and post-LASIK. Aristeidou et $\mathrm{al}^{14}$ evaluated the impact of photorefractive keratectomy and LASIK on RNFL in myopic patients using the same technique. No effect on RNFL thickness was detected in either of the studied groups.

In 2004, in an attempt to evaluate the RNFL function, Hosny ${ }^{15}$ found no significant visual field changes after LASIK. Furthermore, Sharma et $\mathrm{a}^{16}$ compared the effect of LASIK and laser epithelial keratomileusis (LASEK) on RNFL thickness using the time domain OCT with no reported significant changes in RNFL parameters between the preoperative and postoperative measurements. ${ }^{16}$

In this study, a new generation of SD-OCT was used for its higher sensitivity and better resolution in studying the RNFL. With the aid of this machine, it was found that LASIK does not affect RNFL thickness, whether performed with an MMK laser or FS laser, with the latter showing no superior results. Advances with liquid optical interfaces with no applanation at all are being developed to avoid excessive IOP elevation. Further studies on the ganglion cell layers could be of significance.

\section{Acknowledgments}

This research was presented as an oral presentation at the ASCRS meeting in San Francisco, CA, April 2013.

\section{Disclosure}

The authors report no conflicts of interest in this work. None of the authors has any financial interests or relationships to disclose.

\section{References}

1. Lume M, Salgado R, Vaz F, Pinto MC, Furtado MJ, Reimao P. RNFL thickness after LASIK, LASEK and PRK. Ophthalmology Times Europe. 2009;1

2. Sutton G, Hodge C. Accuracy and precision of LASIK flap thickness using the IntraLase femtosecond laser in 1000 consecutive cases. $J$ Refract Surg. 2008;24(8):802-806.

3. Vetter JM, Faust M, Gericke A, Pfeiffer N, Weingärtner WE, Sekundo W. Intraocular pressure measurements during flap preparation using 2 femtosecond lasers and 1 microkeratome in human donor eyes. J Cataract Refract Surg. 2012;38(11):2011-2018.

4. Pablo LE, Ferrera A. Imaging of the retinal fiber layer with spectral domain optical coherence tomography in patients with glaucoma. European Ophthalmic Review. 2010;4(1):17-20.

5. Arthur SN, Smith SD, Wright MM, et al. Reproducibility and agreement in evaluating retinal nerve fibre layer thickness between Stratus and Spectralis OCT. Eye (Lond). 2011;25(2):192-200.

6. Sakata LM, Deleon-Ortega J, Sakata V, Girkin CA. Optical coherence tomography of the retina and optic nerve - a review. Clin Experiment Ophthalmol. 2009;37(1):90-99.

7. Kanamori A, Nakamura M, Tomioka M, Kawaka Y, Yamada Y, Negi A. Agreement among three types of spectral-domain optical coherent tomography instruments in measuring parapapillary retinal nerve fibre layer thickness. Br J Ophthalmol. 2012;96(6):832-837. 
8. Gürses-Ozden R, Pons ME, Barbieri C, et al. Scanning laser polarimetry measurements after laser-assisted in situ keratomileusis. Am JOphthalmol. 2000;129(4):461-464.

9. Tsai YY, Lin JM. Effect of laser-assisted in situ keratomileusis on the retinal nerve fiber layer. Retina (Philadelphia, Pa). 2000;20(4): $342-345$.

10. Gürses-Ozden R, Liebmann JM, Schuffner D, Buxton DF, Soloway BD, Ritch R. Retinal nerve fiber layer thickness remains unchanged following laser-assisted in situ keratomileusis. Am J Ophthalmol. 2001;132(4):512-516.

11. Centofanti M, Oddone F, Parravano M, Gualdi L, Bucci MG, Manni G. Corneal birefringence changes after laser assisted in situ keratomileusis and their influence on retinal nerve fibre layer thickness measurement by means of scanning laser polarimetry. $\mathrm{Br} J$ Ophthalmol. 2005;89(6):689-693.

12. Zangwill LM, Abunto T, Bowd C, Angeles R, Schanzlin DJ, Weinreb RN. Scanning laser polarimetry retinal nerve fiber layer thickness measurements after LASIK. Ophthalmology. 2005;112(2): 200-207.
13. Dada T, Chaudhary S, Muralidhar R, Nair S, Sihota R, Vajpayee RB. Evaluation of retinal nerve fiber layer thickness measurement following laser in situ keratomileusis using scanning laser polarimetry. Indian J Ophthalmol. 2007;55(3):191-194.

14. Aristeidou AP, Labiris G, Paschalis EI, Foudoulakis NC, Koukoula SC, Kozobolis VP. Evaluation of the retinal nerve fiber layer measurements, after photorefractive keratectomy and laser in situ keratomileusis, using scanning laser polarimetry (GDX VCC). Graefes Arch Clin Exp Ophthalmol. 2010;248(5):731-736.

15. Hosny M. Visual field changes after laser in situ keratomileusis. Journal of the Egyptian Society of Cataract and Cornea. 2004;16: 27-29.

16. Sharma N, Sony P, Gupta A, Vajpayee RB. Effect of laser in situ keratomileusis and laser-assisted subepithelial keratectomy on retinal nerve fiber layer thickness. J Cataract Refract Surg. 2006;32(3): 446-450.
Clinical Ophthalmology

\section{Publish your work in this journal}

Clinical Ophthalmology is an international, peer-reviewed journal covering all subspecialties within ophthalmology. Key topics include: Optometry; Visual science; Pharmacology and drug therapy in eye diseases; Basic Sciences; Primary and Secondary eye care; Patient Safety and Quality of Care Improvements. This journal is indexed on

\section{Dovepress}

PubMed Central and CAS, and is the official journal of The Society of Clinical Ophthalmology (SCO). The manuscript management system is completely online and includes a very quick and fair peer-review system, which is all easy to use. Visit http://www.dovepress.com/ testimonials.php to read real quotes from published authors. 